\title{
Long-term changes in the numbers of waterbirds at an important European wintering site
}

\author{
DOMINIK MARCHOWSKI, ${ }^{1}$ ŁUKASZ ŁAWICKI, ${ }^{2}$ SEBASTIAN GUENTZEL, ${ }^{3}$ \\ JACEK KALICIUK, ${ }^{4}$ ZBIGNIEW KAJZER ${ }^{5}$ \\ ${ }^{1}$ Ornithological Station, Museum and Institute of Zoology, Polish Academy of Sciences. Nadwiślańska 108, 80-680 Gdańsk, Poland, \\ e-mail: dominikm@miiz.waw.pl \\ 2 West Pomeranian Nature Society. Wąska 13, 71-415, Szczecin, Poland, e-mail: izuza@interia.pl \\ 3 West Pomeranian Nature Society. Wąska 13, 71-415, Szczecin, Poland, e-mail: limicola@interia.pl \\ ${ }^{4}$ West Pomeranian Nature Society. Wąska 13, 71-415, Szczecin, Poland, e-mail: zboxpl@gmail.com \\ 5 West Pomeranian Nature Society. Wąska 13, 71-415, Szczecin, Poland, e-mail: atricilla@interia.pl
}

Keywords Natura 2000, protected areas, Ducks, Swans, Geese, climate change, Odra River Estuary, NW Poland, wetlands

Abstract Waterbirds were regularly monitored in north-western Poland from 2002 to 2018. Counts took place in the most important areas where wintering waterbirds concentrate in this region, the most important wintering ground for this group of birds in Poland and one of the most important in Europe. In addition to the wintering function, this area also has a very important function as a stopover site for significant numbers of African-Eurasian Flyway migrants. The average number of all waterbirds covered by the study from 2002 to 2018 was 117,000. Numbers in recent years $(2011-2018)$ have increased significantly $(\mathrm{P}<0.001)$ compared to the first half of the study (2002-2010). The most important species found here during the non-breeding period were: Greater Scaup Aythya marila (mean number for 2002-2018: 20,600), Tufted Duck A. fuligula (26,700), Common Pochard A. ferina (1,500), Smew Mergellus albellus $(1,400)$, Goosander Mergus merganser (7,700), Great Crested Grebe Podiceps cristatus (840), Eurasian Coot Fulica atra $(8,400)$, Mute Swan Cygnus olor $(1,100)$, Whooper Swan C. cygnus (890), Taiga/Tundra Bean Goose Anser fabalis sensu lato $(13,000)$ and White-fronted Goose $A$. albifrons $(6,500)$. The importance of this region at the European scale for migratory and wintering waterbirds has increased, and this presents new challenges to the institutions responsible for protecting these areas.

\section{Długoterminowe zmiany liczebności ptaków wodnych w ważnym w skali Europy miejscu zimowania}

Słowa kluczowe Natura 2000, obszary chronione, kaczki, łąbędzie, gęsi, zmiany klimatyczne, estuarium Odry, północno-zachodnia Polska, tereny podmokłe

Streszczenie Od 2002 do 2018 roku prowadzono regularny monitoring ptaków wodnych w północno-zachodniej Polsce. Liczenie przeprowadzono w najważniejszych miejscach zimowania ptaków wodnych w tym regionie, będących jednocześnie ważnymi zimowiskami w Polsce i Europie. 
Poza funkcją zimowiska, miejsca te jednocześnie są ważnymi miejscami przystankowymi dla migrantów przelatujących z Euroazji do Afryki. Średnia liczba wszystkich ptaków wodnych w latach 2002-2018 na badanym obszarze wynosiła 117000 osobników. W porównaniu z latami 2002-2010 w ostatnich ośmiu sezonach zimowych (lata 2011-2018) znacząco wzrosła liczba zimujących ptaków na Pomorzu Zachodnim. Najważniejszymi gatunkami obserwowanymi na badanym obszarze w okresie pozalęgowym były: ogorzałka Aythya marila (średnio 20600 osobników), czernica $A$. fuligula (26 700), głowienka A. ferina (1500), bielaczek Mergellus albellus (1400), nurogęś Mergus merganser (7700), perkoz dwuczuby Podiceps cristatus (840), łyska Fulica atra (8400), łabędź niemy Cygnus olor (1100), łabędź krzykliwy C. cygnus (890), gęś zbożowa/tundrowa Anser fabalis sensu lato (13 000) i gęś białoczelna A. albifrons (6500). Znaczenie tego regionu dla ptaków migrujących i zimujących w skali Europy rośnie, co tworzy nowe wyzwania dla instytucji odpowiedzialnych za ochronę tych obszarów.

\section{Introduction}

Bird monitoring has become an important tool in environmental monitoring. Such programmes have been implemented for many decades (Magurran et al., 2010). Waterbirds have been used as bioindicators in environmental monitoring for many years (Wetlands International, 2010). Many international institutions, such as HELCOM (Helsinki Convention on the Protection of the Marine Environment of the Baltic Sea Area), ICES (International Council for the Exploration of the Sea), BirdLife International or the European Union, use bird monitoring data to predict changes in the environment. The International Waterbirds Census (IWC) is a worldwide programme that has been monitoring waterbirds for many years (Mundkur et al., 2017). As part of this programme, wintering waterbirds are counted on one occasion in January, the count usually taking place at the same time each year using the same methodology (Wetlands International, 2010). The West Pomeranian Nature Society (Polish: Zachodniopomorskie Towarzystwo Przyrodnicze, hereafter ZTP) is a non-governmental organisation that carries out such monitoring on the one of the most important waterbird wintering areas in Europe. The results of the January counts are transferred to Wetlands International based in the Netherlands, the organization that coordinates the IWC. In addition to the January counts, ZTP carries out two extra counts using the same methodology in November and March. As a result, we have more precise information on the numbers and distribution of birds, not only during the winter but also during the autumn and spring migrations. The site monitored by ZTP is not accidental. The north-western part of Poland is one of the most important waterbird wintering areas in Europe (Skov et al., 2011), and the region is particularly important for species such as Greater Scaup Aythya marila (hereafter Scaup), Common Pochard Aythya ferina (hereafter Pochard), Goosander Mergus merganser and Smew Mergellus albellus (Marchowski et al., 2017, 2018). This article summarises the results of the monitoring of several key bird species and the changes in their numbers over a period of 17 years.

\section{Materials and methods}

\section{Study area}

The study area lies in north-western Poland and covers the most important areas where waterbirds congregate during the non-breeding period. These areas are located mainly along the Odra River valley and in the Odra estuary, which includes the Szczecin Lagoon, the Kamien Lagoon and Lake Dąbie. The monitoring also covers Lake Miedwie and the fishponds in 
Dzwonowo - these two sites lie beyond the Odra valley and the estuary (Figure 1). The study site covers an area of around 1,200 $\mathrm{km}^{2}$ and about $420 \mathrm{~km}$ of river banks and waterbody shores.

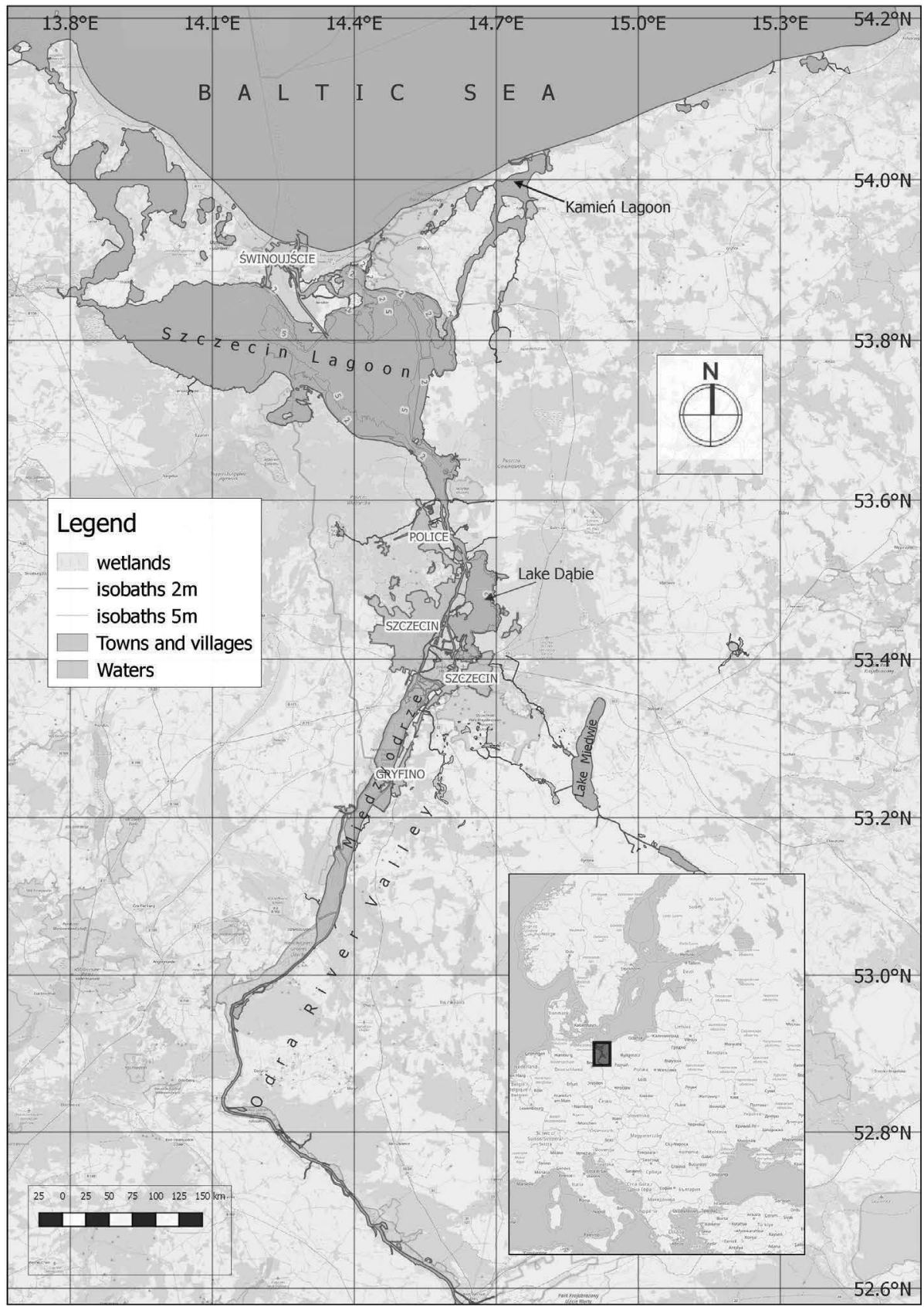

Figure 1. The study area 
Odra Valley. The section between Kostrzyn and Szczecin $(120 \mathrm{~km})$ is characterised by quite diverse habitats. There are regulated sections with stone groynes and flood embankments; unregulated sections that are periodically flooded such as Kostrzyneckie Rozlewisko, around the village of Piasek, or the section from Czelin to Kłosów; oxbow lakes and mosaics of wetland habitats from flooded meadows, reed beds and compact willow scrub to waterlogged forests between Widuchowa and Szczecin. Also typical of the region are habitats strongly transformed by man, such as ports, harbours, shipyards, wharves, sewage treatment plants and artificially heated waters: such habitats occur mainly in the vicinity of the Szczecin-Police-Gryfino conurbation in the middle of the study area.

Odra River Estuary. The average and maximum depths of the estuary are 3.8 and $8.5 \mathrm{~m}$, respectively (the dredged shipping lane cutting across the bottom of Lagoon from Baltic Sea to the port of Szczecin is $10.5 \mathrm{~m}$ deep) (Radziejewska, Schernewski, 2008). The waters of the Szczecin Lagoon, Kamień Lagoon and Lake Dąbie are brackish. The salinity in the central part varies from $0.3 \mathrm{psu}$ (practical salinity unit) to $4.5 \mathrm{psu}(\mathrm{mean}=1.4 \mathrm{psu})$ and declines with increasing distance from the sea (Radziejewska, Schernewski, 2008). Periodic inflows of water from the Pomeranian Bay (salinity $\sim 7 \mathrm{psu}$ ) take place through the Świna Strait and, to a lesser extent, through the Dziwna and Peene Straits (the latter in the German part of the ORE). Large communities of benthic organisms such Zebra Mussels Dreissena polymorpha, which occur here on a very large scale (Wolnomiejski, Woźniczka 2008), provide a source of food for benthic feeding birds (Marchowski et al., 2015, 2016).

Lake Miedwie. In comparison to the Odra estuary, Lake Miedwie is deep, its maximum depth being $43.8 \mathrm{~m}$. As it lies at a height of $14 \mathrm{~m}$ above sea level, this makes it the place with the largest cryptodepression in Poland (29.8 m below sea level). The lake has an area of $35 \mathrm{~km}^{2}$ and a shoreline $39 \mathrm{~km}$ in length. The shores of the lake are mainly surrounded by a landscape of arable fields, meadows, pastures and wetlands.

Dzwonowo fish ponds. The ponds are used for fish farming, producing stocking material and carp for human consumption. The 36 ponds cover a total area of 365 hectares. The largest pond for commercial carp production is 138 hectares in area.

\section{Methods}

Our counts included Grebes (Podicipediformes), Ducks, Geese and Swans (Anseriformes) and Gruiformes. The species nomenclature and the systematic order used in the article are in accordance with the latest version of the HBW and BirdLife Taxonomic Checklist (HBW \& BirdLife International, 2017). The following way of listing species in the text (e.g. Marchowski et al., 2015, 2017), standard in ornithological publications, has been adopted: when the species name appears for the first time, the full English name is given along with the full scientific name (genus and species - in italics); whenever a species is referred to again in the text, the English name only is used.

A total of 46 counts were conducted in 2002-2018. When calculating the mean number of birds for each season, a season was treated as the period from November (the first count) in one year to January and March (the second and third counts) in the following year. Only one count took place in the 2001/2002 season (in January), and no counts were done in the 2006/2007 season. Therefore, we have data for 15 full seasons. No observations were made during extreme weather conditions (heavy rain, high wind, strong wave action). Counts were carried out on the ground and from the air; the alternative terms 'platform' and 'census method' are used in the text 
to refer to the 'count method'. All count results were raw data: numbers were not processed by any calculations, such as distance analysis. We used 'total count' methods with both platforms. This 'total count' method has also been used in other studies (Joasen, 1968, Savard, 1982, Kingsford, 1999, Voslamber, van Turnhout, 1999, Laursen et al., 2008). A team of about 20 trained and experienced observers was involved in all the counts.

A slow-flying, high-wing aeroplane was used for the aerial counts. The average flight speed was about $100 \mathrm{~km} / \mathrm{h}$ and the average flying height was about $80 \mathrm{~m}$ above the water. This gave a roughly $1500 \mathrm{~m}$ wide band within which birds could be recorded. The flight route was designed to cover as much of the water surface as possible; we estimated that coverage was thus approximately $95 \%$ of the area surveyed. Only the birds in a very small part of the middle of the Szczecin Lagoon (the largest water body in the survey area - see Figure 1) were not counted.

Ground counts were usually done on foot, although cars were also involved. Each observer was equipped with $10 \times 40$ or $10 \times 50$ binoculars and tripod-mounted spotting scopes with variable magnification, usually 20-60×. During the counts, observers walked along the same routes, stopping every few hundred metres to scan the area with binoculars and/or spotting scope and then count the birds. Alternatively, counts were conducted from vantage points accessible by car. We used the best vantage points and routes, dividing the study area up into areas that were visible from such points or routes so that no counted areas overlapped and no parts of the study area were overlooked. The present analysis took only birds on the water into consideration. All the counts were carried out from the same routes and observation points.

The methodology of the ground and aerial counts is consistent with generally accepted standards in this field (Komdeur et al., 1992; Wetland International, 2010) and is described for our study area in more detail by Marchowski et al. (2018).

\section{Statistical calculations}

We analysed the data from 15 seasons in the period 2002-2018. All the statistics were performed using R software (R Development Core Team 2014). Because of the small sampling size ( $\mathrm{n}=15$ seasons) we could not assume a normal distribution, so we used the simple bootstrap method to estimate means, standard error and confidence intervals. Bootstrap works well with samples that have less than 40 elements, because it involves resampling (Jain et al., 1987). To check the statistical significance of the differences between the first half of the study period (2002-2010) and the second half(2011-2018), we used a permutation test based on resampling without replacement. This test does not rely on assumptions about the distribution of the data. Permutation tests work by resampling the observed data many times in order to determine a p-value for the test (Hothorn et al., 2015). Results were considered statistically significant for $\mathrm{P}<0.05$ and close to statistical significance for $\mathrm{P}<0.1$.

\section{Results}

The average number of waterbirds in the non-breeding periods in the studied area in 20022018 was 116,968 ( $\pm 5,498 \mathrm{SE})$. The mean autumn number was 128,933 $( \pm 14,244 \mathrm{SE})$, the mean spring number was 122,994 ( $\pm 11,152 \mathrm{SE})$ birds, and the mean winter number was $98,997( \pm 10,774$ $\mathrm{SE})$. The numbers from each season are shown separately in Figure 2 . The mean number from the first half of the survey (2002-2010) was 86,542 ( $(7,101$ standard error $-\mathrm{SE}$, confidence intervals 
- 95\% CI: 73,$294 ; 101,032)$ ind., while that from the remaining seasons was $147,403( \pm 8,439 \mathrm{SE}$ $95 \% \mathrm{CI}=131,191 ; 164,170)$ ind.; this indicates that the number of birds increased significantly over time $(\mathrm{P}<0.001)$ (Figure 3$)$. The lowest number of waterbirds was recorded in January $2010-38,320$, and the highest in November $2017-225,335$.

\section{The most important bird species}

Scaup Aythya marila. The mean for 2002-2018 was 20,613 ( \pm 1790 SE), the lowest number ( 2 birds) was recorded in January 2004, and the highest number $(83,330)$ in November 2014 (an exceptionally high number $(95,500)$ was recorded outside the counting period, in April 2011) (Lawicki, Guentzel, 2012). The mean number from the first half of the survey (2002-2010) was $11,320$ ( $\pm 2,590 \mathrm{SE} ; 95 \%$ CI: 6,$883 ; 16,942)$; for the second half $(2011-2018)$ the figure was 28,740 $( \pm 4,264 \mathrm{SE} ; 95 \% \mathrm{CI}=20,847 ; 37,522)$, indicating that the numbers of these ducks increased significantly over time $(\mathrm{P}=0.002)$ The most important area for Scaup was the Szczecin Lagoon; high numbers were also regularly recorded on Lake Dąbie.

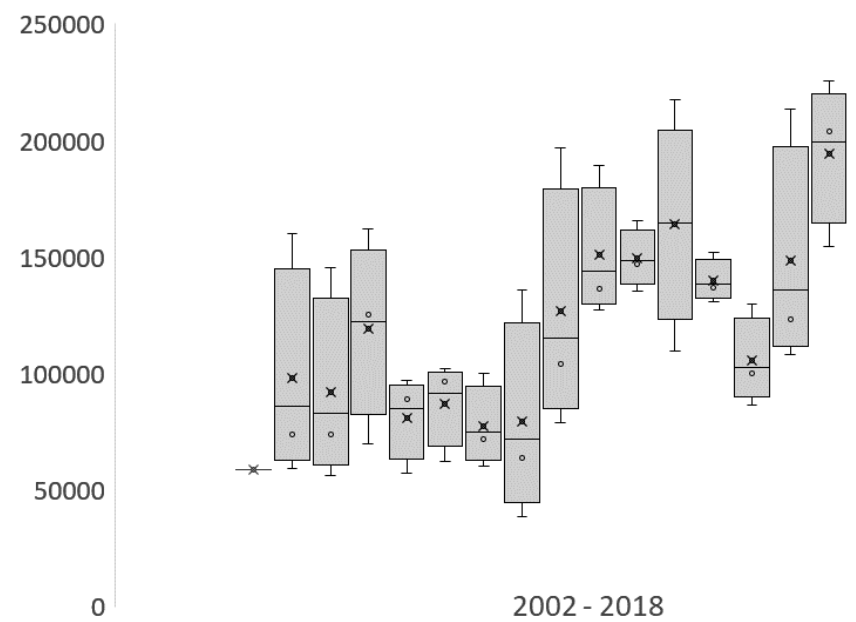

Figure 2. Changes in the abundance of all waterbird species counted in the whole study area in 2002-2018. Results of three counts during the non-breeding period (November, January and March). The years on the $x$-axis represent all three counts in one season, e.g. 2003 is the 2002/2003 season, etc. Only one count was carried out in the 2002 season (2001/2002) (in January). Each plot box gives the following information: minimum value, maximum value, intermediate value (small circle), mean (small $\times$ ), median (line), upper and lower quartile (box).

Tufted Duck Aythya fuligula. The mean for 2002-2018 was 26,680 ( $\pm 1,635$ SE) birds, the lowest number (516) was recorded in January 2004, and the highest one $(57,276)$ in November 2014. The mean number for the first half of the survey (2002-2010) was $18,912( \pm 2,885 \mathrm{SE} ; 95 \%$ CI: 13,386; 24,676); for the second half (2011-2018) it was 33,483 ( $\pm 3,093$ SE; $95 \%$ CI: 27,341; $39,455)$, indicating that the number of birds increased significantly over time $(\mathrm{P}=0.003)$. The most important area for Tufted Duck was the Szczecin Lagoon, but high numbers were also regularly 
recorded on Lake Dąbie. Tufted Duck was much more dispersed than Scaup and was regularly observed in other areas such as the Odra Valley and Lake Miedwie.

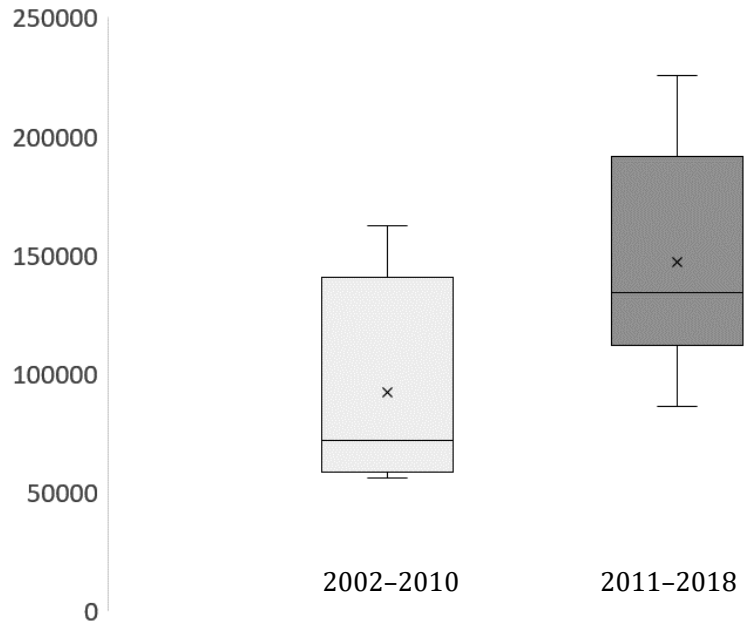

Figure 3. All species of waterbirds in the study area, aggregate numbers from the first half of the study period (2002-2010) and from the second half (2011-2018). Each plot box gives the following information: minimum value, maximum value, intermediate value, mean (small $\times$ ), median (line), upper and lower quartile (box).

Pochard Aythya ferina. The mean for 2002-2018 was 1,483 ( \pm 156 SE) birds, the lowest number (0) was recorded in January 2003, and the highest number $(4,935)$ in January 2005. The mean number for the first half of the survey (2002-2010) was 1,839 ( $\pm 357 \mathrm{SE}$; 95\% CI: 1,163; 2,557); for the second half (2011-2018) it was $1,171( \pm 160 \mathrm{SE}$; 95\% CI: 871; 1,497). This indicates that the number of birds decreased over time, but the result is marginally insignificant $(\mathrm{P}=0.1)$. The most important area for Pochard was the Szczecin Lagoon, while high numbers were also regularly recorded on Lake Dąbie. Like Tufted Duck, Pochard was more dispersed than Scaup and was regularly sighted in other areas such as the Odra Valley and Lake Miedwie.

Common Goldeneye Bucephala clangula. The mean for 2002-2018 was 3,493 ( $\pm 170 \mathrm{SE})$ birds, the lowest number (198) was recorded in January 2010, and the highest number $(10,971)$ in March 2011. The mean number for the first half of the survey (2002-2010) was 2,846 $( \pm 333$ SE; 95\% CI: 2,212; 3,515); for the second half (2011-2018) it was 4,055 ( \pm 435 SE; 95\% CI: 3,265; $4,965)$. Numbers of these ducks thus increased significantly over time $(\mathrm{P}=0.05)$. Goldeneye was dispersed throughout the study area, the highest numbers being found in the Szczecin Lagoon, on Lake Dąbie and in the Odra Valley.

Eurasian Coot Fulica atra. The mean for 2002-2018 was 8,356 ( $\pm 561 \mathrm{SE})$ birds, the lowest number (563) was recorded in January 2003, and the highest number $(24,836)$ in November 2004. The mean number for the first half of the survey (2002-2010) was 7,675 $( \pm 1,382 \mathrm{SE}$; 95\% CI: 5,247 ; 10,619); for the second half (2011-2018) it was 8,952 ( \pm 846 SE; 95\% CI: 7,361; 10,673). The increase in numbers was not significant over time $(\mathrm{P}=0.45)$. Coot was dispersed all over the study area, but the most important subareas were Lake Dąbie, the Kamien Lagoon and the Odra Valley. 
Smew Mergellus albellus. The mean for 2002-2018 was 1,388 ( \pm 97 SE) birds, the lowest number (116) was recorded in January 2006, and the highest one $(3,770)$ in January 2009. The mean number for the first half of the survey (2002-2010) was 1,465 ( \pm 212 SE; 95\% CI: 1,059; 1,889); for the second half (2011-2018) it was 1,311 ( \pm 229 SE; 95\% CI: 887; 1,781), indicating insignificant changes over time $(\mathrm{P}=0.63)$. Smew were found throughout the study area, but the largest concentrations were in the Szczecin Lagoon, on Lake Dąbie and the Kamien Lagoon.

Goosander Mergus merganser. The mean for 2002-2018 was 7,670 ( $\pm 673 \mathrm{SE}$ ) birds, the lowest number (429) was recorded in November 2016, and the highest number $(24,000)$ in January 2009. The mean number for the first half of the survey (2002-2010) was 8,751 ( $\pm 1,643 \mathrm{SE}$; $95 \%$ CI: 5,646; 12,070); for the second half(2011-2018) it was 6,589 ( $\pm 1,255$ SE; 95\% CI: 4,297; 9,205), indicating an insignificant decrease over time $(\mathrm{P}=0.31)$. Goosander was found throughout the study area, but the largest flocks were in the Szczecin Lagoon and on Lake Dąbie.

Great Crested Grebe Podiceps cristatus. The mean for 2002-2018 was 839 ( $\pm 78 \mathrm{SE}$ ) birds, the lowest number (70) was recorded in January 2003, and the highest one $(8,100)$ in January 2014. The mean number for the first half of the survey (2002-2010) was 522 ( $\pm 107 \mathrm{SE}$; $95 \%$ CI: 349; 761); for the second half (2011-2018) it was 1,155 ( $\pm 161 \mathrm{SE}$; 95\% CI: 854; 1,485), indicating a significant increase over time $(\mathrm{P}=0.002)$. Great Crested Grebe was found on large water bodies, hence the largest concentrations were in the Szczecin Lagoon and on Lake Miedwie. It was rather rare in the Odra Valley.

Mallard Anas platyrhynchos. The mean for 2002-2018 was 13,418 ( $\pm 588 \mathrm{SE})$ birds, the lowest number $(1,300)$ was recorded in March 2005, and the highest number $(26,500)$ in March 2018. The mean number for the first half of the survey (2002-2010) was 12,522 ( $\pm 1,210 \mathrm{SE}$; 95\% CI: 10,227 ; 14,970); for the second half(2011-2018) it was 14,315 ( $\pm 1,406$ SE; 95\% CI: 11,606; 17,108); this indicated a non-significant increase over time $(\mathrm{P}=0.349)$. Mallard was found everywhere, but there were sites where considerable numbers congregated, especially during poor weather. During below-zero temperatures, these ducks tended to remain in the Szczecin - Police - Gryfino conurbation, but in frost-free winters, they could be found in localities such as the Kostrzyneckie Rozlewisko in the Odra Valley and small bays on Lake Dąbie, Lake Miedwie and the Kamień Lagoon.

Mute Swan Cygnus olor. The mean for 2002-2018 was 1,115 ( $\pm 41 \mathrm{SE})$ birds, the lowest number $(157)$ was recorded in January 2010, and the highest one $(2,500)$ in January 2016 . The mean number for the first half of the survey (2002-2010) was 932 ( $\pm 90 \mathrm{SE} ; 95 \% \mathrm{CI}: 763 ; 1114)$; for the second half (2011-2018) it was 1,299 ( \pm 78 SE; 95\% CI: 1,154; 1,460), a significant increase over time $(\mathrm{P}=0.04)$. Important areas for Mute Swan were extensive water bodies such as the Szczecin Lagoon, the Kamień Lagoon, Lake Dąbie and Lake Miedwie.

Whooper Swan Cygnus cygnus. The mean for 2002-2018 was 892 ( \pm 66 SE) birds, the lowest number (18) was recorded in March 2014, and the highest number $(2,700)$ in March 2004. The mean number for the first half of the survey (2002-2010) was 769 ( \pm 118 SE; 95\% CI: 562; 1021); for the second half (2011-2018) it was 1,016 ( $\pm 159 \mathrm{SE} ; 95 \% \mathrm{CI}: 712 ; 1,333)$, a non-significant increase over time $(\mathrm{P}=0.23)$. Whooper Swan was seen more often and in greater numbers in the Odra Valley, on Lake Miedwie and the eastern Szczecin Lagoon.

Tundra Swan Cygnus columbianus. The mean for 2002-2018 was 34 ( \pm 3 SE) birds, the lowest number (0) was recorded during several counts, while the highest number (142) was recorded in March 2004. The mean number for the first half of the survey (2002-2010) was 46 ( $\pm 8 \mathrm{SE}$; $95 \% \mathrm{CI}$ : 30 ; 63); for the second half (2011-2018) it was 23 ( \pm 6 SE; 95\% CI: 13; 34), indicating a significant 
decrease over time $(\mathrm{P}=0.03)$. This species was found mainly on Lake Miedwie, the Dzwonowo fish ponds and in the Odra Valley.

Tundra/Taiga Bean Goose Anser fabalis sensu lato (Bean Goose complex Anser fabalis/ serrirostris). The mean for 2002-2018 was 13,330 ( \pm 1113 SE) birds, the lowest number (89) was recorded in March 2005, and the highest number $(30,000)$ in January 2013. The mean number for the first half of the survey (2002-2010) was 14,545 ( $\pm 2,036$ SE; 95\% CI: 10,767; 18,730); for the second half (2011-2018) it was 12,114 ( $\pm 1,810$ SE; 95\% CI: 8,672; 15,744) - a non-significant decrease over time ( $\mathrm{P}=0.389)$. The main area for Bean Goose complex was the Odra valley, mainly the Kostrzyneckie Rozlewisko and Międzyodrze. Other important sites were Lake Miedwie and the Kamień Lagoon. It must be emphasized that the vast majority of Bean Goose complex wintering and migrating through our study area belongs to Tundra Bean Goose Anser serrirostris.

White-fronted Goose Anser albifrons. The mean for 2002-2018 was 6,454 ( $\pm 845 \mathrm{SE})$ birds, the lowest number (0) was recorded in January 2010, and the highest number $(40,400)$ in March 2003. The mean number for the first half of the survey (2002-2010) was $8,602( \pm 2,192 \mathrm{SE} ; 95 \%$ CI: 4,775; 13,307); for the second half (2011-2018) it was 4,304 ( \pm 717 SE; 95\% CI: 2,993; 5,792), indicating a marginally non-significant decrease over time $(\mathrm{P}=0.07)$. Geese gather in similar places, creating mixed flocks. Hence, the most important areas are the same for White-fronted Goose as for Bean Goose complex. The proportion of White-fronted Goose in mixed flocks was slightly higher at Międzyodrze than at other sites.

\section{Discussion}

In north-western Poland, numbers of water birds as a group have increased over the last two decades. This situation can be explained by climate warming, because this phenomenon has been already demonstrated for some waterbird species wintering at these latitudes (Lehikoinen et al., 2013, Pavon-Jordan et al., 2015, Marchowski et al., 2017). The shifting boundaries of birds' ranges as a result of climate change may be variously manifested in the study area: numbers of some species are on the increase, others are decreasing. Looking at the individual species, the situation is much more complex than the overall pattern would suggest: the causes of changes in numbers can be quite different. Depending on the species, increases or decreases in number may have the same cause, or the same direction of change may have different causes (Marchowski et al., 2017).

Goosander numbers have decreased in our study area, but during the period of study (20022018) the changes were not significant. Before the start of this research, however, Goosander numbers were higher. Some 30 years ago, mean winter numbers (1991-1993) were 27,900 with a maximum of 33,100 birds (Meissner et al., 1993, Meissner, 1994); more recently (2016-2018), mean winter numbers were 14,600 ind. with a maximum of 21,300. More advanced calculations, taking into account such predictors as the size of the entire flyway population and ice cover, showed a decreasing trend in 2002-2016 (Marchowski et al., 2017). The probable decrease in abundance can be explained by the wintering grounds shifting farther east and north, where numbers have increased (Lehikoinen et al., 2013). The same applies to Smew: in the early 1990s, mean winter numbers of this species were 7,300 (1991-1993) with a maximum of 19,700 birds (Meissner, Kozakiewicz, 1992), whereas in recent years (2016-2018) the mean winter number was down to 1,400 with a maximum of 1,900 birds. That Smew's wintering areas have shifted further to the north and east has been demonstrated by Pavon-Jordan et al. (2015).

The reverse situation applies to two other species that winter in our area - Scaup and Tufted Duck. The abundances of these species have increased significantly in the last two decades: the 
reason behind these changes is the same as in the two previous species. But the difference is that the main wintering grounds of Scaup and Tufted Duck are situated farther west and south in Europe than our study area. Hence, as a result of the eastward and northward shift of their wintering grounds, the abundances of these two species have locally increased (Lehikoinen et al., 2013, Marchowski et al., 2017).

In some species, number reductions can be explained by global trends. A good example is Tundra Swan, in which both the flyway and local populations have decreased significantly (Wetlands International, 2017). In contrast, local growth trends of other species are in line with global ones (Wetlands International, 2017, 2018). Our local examples are Mute Swan, Common Goldeneye and Great Crested Grebe, the numbers of which have all significantly increased.

With regard to Pochard, the lack of significant changes in the study period and the steep decline in the global populations of this species (Fox et al., 2016) highlights the importance of the study area for this species.

The numbers of two species - Whooper Swan and Mallard - have remained at the same level during the last two decades. The flyway population of the first has increased strongly (Wetlands International, 2017), so our local situation could also be explained by the shift of these birds' wintering grounds further to the north and east, but there is no proof of this. In contrast, the lack of directional changes in Mallard numbers in the study area along with a moderate decrease in the entire flyway population (Wetlands International, 2017) is hard to explain, because the population trends in this species as reported by various sources have been variously assessed (e.g. BirdLife International, 2015, Wetlands International, 2018).

The situation regarding the final two species is likewise not very clear and hard to explain. The trends differ from the global ones, but they cannot be explained by a shift in the wintering range because there is no proof of this. For example, the flyway population of Tundra Bean Goose (subspecies Anser serrirostris rossicus, mainly wintering in the study area) is growing but in our area it is stable; in contrast, the flyway population of White-fronted Goose is stable (Wetlands International, 2018) but its numbers in our study area are decreasing (marginally nonsignificantly). This may be due to the slightly different methodology adopted at the beginning of the research period, and to the fact that more sites have been monitored (for Geese only) including the German side of the Odra valley.

In summary, we can say that north-western Poland (the province of Western Pomerania) remains an important wintering area for waterbirds in Europe. Natura 2000 sites were established here to provide effective protection for this group of birds. The effects of climate change and other causes have led to changes in the numbers of individual species and whole groups. On balance, however, the importance of this region of Europe as a wintering site for waterbirds has increased, the main reason for this being climate warming. This presents new challenges to the institutions responsible for environmental conservation in these areas. The individual fates of each species are different - some species are decreasing, others are increasing. A thorough knowledge of the causes of these phenomena at the level of particular species and their life cycle will enable them to be effectively protected in these important locations.

\section{Acknowledgements}

We thank all the people who took part in the fieldwork - mainly members of the WestPomeranian Nature Society - but especially those who were the most active during the entire study period: Michał Barcz, Michał Jasiński, Krzysztof Kordowski, Andrzej Kostkiewicz, Aneta 
Kozłowska, Wojciech Mrugowski, Paweł Pluciński, Bartosz Racławski, Tomasz Rek, Artur Staszewski, Marcin Sołowiej, Paweł Stańczak and Mirosław Żarek. The study was funded by the West Pomeranian Nature Society (ZTP) and the Polish Society for the Protection of Birds (OTOP). Some of the counts were financed from the resources of the Provincial Fund for Environmental Conservation in Szczecin and from the National Fund for Environmental Conservation in Warsaw.

\section{References}

BirdLife International (2015). European Red List of Birds. Office for Official Publications of the European Communities. Luxembourg. Retrieved from: http://datazone.birdlife.org/info/euroredlist.

Fox, A.D., Caizergues, A., Banik, M.V., Devos, K., Dvorak, M., Ellermaa, M., Folliot, B., Green, A.J., Grüneberg, C., Guillemain, M., Håland, A., Hornman, M., Keller, V., Koshelev, A.I., Kostiushyn, V.A., Kozulin, A., Ławicki, Ł., Luingujoe, L., Müller, C., Musil, P., Musilová, Z., Nilsson, L., Mischenko, A., Pöysä, H., Ščiban, M., Sjeničić, J., Stipniece, A., Švažas, S., Wahl, J. (2016). Recent changes in the abundance of Common Pochard Aythya ferina breeding in Europe. Wildfowl, 66, 22-40.

HBW and BirdLife International. (2017). Handbook of the Birds of the World and BirdLife International digital checklist of the birds of the world. Version 2. Retrieved from: http://datazone.birdlife.org/userfiles/file/Species/Taxonomy/HBW-BirdLife_Checklist_Version_2.zip [.xls zipped $1 \mathrm{MB}$ ].

Hothorn, T., Hornik, K., van de Wiel, M.A., Zeileis A. (2015). Implementing a Class of Permutation Tests: The coin Package. Retrieved from: cran.r-project.org/web/packages/coin/vignettes/coin_implementation.pdf.

Jain, A.K., Dubes, R.C., Chen, C.-C. (1987). Bootstrap Techniques for Error Estimation. IEEE Transactions on Pattern Analysis and Machine Intelligence, 9, 628-633. DOI: 10.1109/TPAMI.1987.4767957.

Joasen, AH. (1968). Wildfowl counts in Denmark in November 1967 and January 1968. Methods and results. Danish Review of Game Biology, 9, 1-206.

Laursen, K, Frikke, J, Kahlet, J. (2008). Accuracy of 'total counts' of waterbirds from aircraft in coastal waters. Wildlife Biology, 14, 165-175.

Lehikoinen, A., Jaatinen, K., Vahatalo, A.V., Preben, C., Crowe, O., Deceuninck, B., Hearn, R., Holt, C.A., Hornman, M., Keller, V, Nilsson, L, Langendoen, T., Tomankova, I., Wahl, J., Fox, A.D. (2013). Rapid climate changes driven shifts in wintering distributions of three common waterbird species. Global Change Biology, 19, 2071-2081. DOI: 10.1111/gcb.12200.

Ławicki, Ł., Guentzel, S. (2012). Important Bird Areas in Poland. Inventory of non-breeding species in the 2011/2012 season. Szczecin: Eco-Expert.

Magurran, A.E., Baillie, S.R., Buckland, S.T., Dick, J.M., Elston, D.A., Scott, E.M., Smith, R.I., Paul, J. Somerfield, P.J., Watt, A.D. (2010). Long-term datasets in biodiversity research and monitoring: assessing change in ecological communities through time. Trends in Ecology and Evolution, 25, 574582. DOI:10.1016/j.tree.2010.06.016.

Marchowski, D., Neubauer, G., Ławicki, Ł., Woźniczka, A., Wysocki, D., Guentzel, S., Jarzemski, M. (2015). The importance of non-native prey, the Zebra Mussel Dreissena polymorpha, for the declining Greater Scaup Aythya marila: a case study at a key European staging and wintering site. PLoS ONE, 10 (12), e0145496. DOI 10.1371/journal.pone.0145496.

Marchowski, D., Jankowiak, Ł., Wysocki, D., Ławicki, Ł., Girjatowicz, J. (2017). Ducks change wintering pattern due to changing climate in the important wintering waters of the Odra River Estuary. PeerJ, 5, e3604. DOI: //doi.org/10.7717/peerj.3604.

Marchowski, D., Jankowiak, Ł., Ławicki, Ł., Wysocki, D. (2018). Waterbird counts on large water bodies: comparing ground and aerial methods during different ice conditions. PeerJ. DOI 10.7717/peerj.5195. 
Meissner, W., Kozakiewicz, M. (1992). Aerial survey along Polish Baltic coast in January 1991. IWRB Seaduck Bulletin, 1, 21-22.

Meissner, W., Kozakiewicz, M., Skakuj, M. (1993). The number and distribution of wintering waterfowl along the Polish Baltic coast in 1993. Ring, 15, 375-377.

Meissner, W. (1994). Midwinter Counts along the Polish Coast of the Baltic, 1992 and 1993. IWRB Seaduck Research Group Bulletin, 4, 26-30.

Mundkur, T., Langendoen, T., Watkins, D. (eds.) (2017). The Asian Waterbird Census 2008-2015 - results of coordinated counts in Asia and Australasia. Ede: Wetlands International.

Pavon-Jordan, D., Fox, A.D., Clausen, P., Dagys, M., Deceuninck, B., Devos, K., Hearn, R.D., Holt, C.A., Hornman, M., Keller, V., Langendoen, T., Ławicki, Ł., Lorentsen, S.H., Luiguj, L., Meissner, W., Musil, P., Nilsson, L., Paquet, J.Y., Stipniece, A., Stroud, D.A., Wahl, J., Zenatello, M., Lehikoinen, A. (2015). Climate-driven changes in winter abundance of a migratory waterbird in relation to EU protected areas. Diversity Distrib., 21, 571-582.

R Core Team (2014). R: A Language and Environment for Statistical Computing. R Foundation for Statistical Computing, Vienna, Austria. Retrieved from: http://www.R-project.org.

Radziejewska, T., Schernewski, G. (2008). The Szczecin (Oder) Lagoon. In: U. Schiewer (ed.), Ecology of Baltic Coastal Waters (pp: 116-117). Berlin Heidelberg: Springer.

Savard, J-PL. (1982). Variability of waterfowl aerial surveys: observer and air - ground comparisons. A preliminary report. Canadian Wildlife Service, 127, 1-6.

Voslamber, B., van Turnhout, C. (1999). Vergelijkende studie van land- en vligtuigtellingen van watervogels in het Ijsselmeergebied. RIZA-rapport BM99.01. SOVON-onderzoeksrapport 1999/08, 66 pp.

Wetlands International (2010). Guidance on waterbird monitoring methodology: Field protocol for waterbird counting. Wageningen: Wetlands International. Retrieved from: http://www.wetlands.org.

Wetlands International (2017). Flyway trend analyses based on data from the African-Eurasian Waterbird Census from the period of 1967-2015. Ede: Wetlands International. Retrieved from: http://iwc.wetlands.org/index.php/aewatrends.

Wetlands International (2018). Waterbird Population Estimates. Retrieved from: wpe.wetlands.org (20.08.2018).

Wolnomiejski, N., Woźniczka, A. (2008). A drastic reduction in abundance of Dreissena polymorpha Pall. in the Skoszewska Cove (Szczecin Lagoon, River Odra estuary): effects in the population and habitat. Ecological Questions, 9, 103-111.

Cite as: Marchowski, D., Ławicki, Ł., Guentzel, S., Kaliciuk, J., Kajzer, Z. (2018). Long term changes in numbers of waterbirds at an important European wintering site. Acta Biologica, 25, 111-122. DOI: 10.18276/ab.2018.25-09. 